\title{
Forecasting Performance of Commercial Property Investments in Lagos Metropolis
}

\author{
Obinna Umeh ${ }^{1}$ and Chibuikem Adilieme ${ }^{2}$ \\ 1-2 Department of Estate Management, University of Lagos, Nigeria.
}

To cite this article: Umeh, O. \& Adilieme, C. (2020). Forecasting Performance of Commercial Property Investments in Lagos Metropolis. Journal of African Real Estate Research, 5(2), pp.59-74. DOI: 10.15641/jarer.v5i2.915.

\begin{abstract}
Investors rely on statistical forecasts to guide their investment decisions. Given the relative opportunity cost associated with these decisions, and the huge financial implication of commercial property investments, such insights are invaluable; because investors can choose investments from an informed position. Despite this recognised benefit of forecasting, there has been little focus on forecasting the performance (total returns) of commercial property investments in Lagos Metropolis. This paper, therefore, aims to forecast the total returns of two commercial property investment types (shops and offices) in five sub-markets (Yaba, Ikeja, Ikoyi, Victoria Island and Lagos Island) within the Lagos property market. In doing so, the study uses longitudinal data for the capital and rental values of commercial property investments in Lagos between 2006 to 2018 alongside a simple regression model for 20192021 predicted total returns. Autocorrelation was used in testing the predictive validity of this data set. Furthermore, multiple forecasts were evaluated simultaneously for accuracy and, together, they illustrate the difficulty of compiling a robust dataset in the absence of a central database. This paper suggests that the sampled total returns for the five sub-markets fluctuate and tend to decline as seen in the Ordinary Least Square Regression technique for 2019 to 2021. The results also suggest a low autocorrelation in most of the sub-markets, which indicates that the observed pattern of returns may not continue. This paper recommends that investors be wary of commercial property investment in Lagos Metropolis, due to the observed poor performance (low and fluctuating total returns). It is also recommended that a property database be constructed to improve property data reliability and allow for the application of complex quantitative forecasting techniques.
\end{abstract}

Keywords: Real Estate Investment; Forecasting; Investment Performance; Lagos Metropolis; Nigeria

\footnotetext{
1 umelobinna@gmail.com

2 adiliememichael@gmail.com
} 


\section{Introduction}

Real estate investment refers to the commitment of a capital sum in exchange for future benefits such as an income flow or capital gain, or a combination of both (Hargitay \& Yu, 1993). The financial implications of real estate investment are substantial and, therefore, investors require data on possible trends to enable them to make sound investment decisions (Ogbuefi, 2002). The use of historic data to estimate possible future trends is commonly referred to as forecasting. According to DeLurgio (1998), forecasting forms an integral part of any decision-making process. It attempts to decrease the dependence on chance and provide some way to predict future events. Forecasting is an indispensable activity in property investment (Mitchell \& McNamara, 1997). Umeh (2017) in reaffirmation and furtherance, opines that forecasting is the lifeblood of most successful investment decisions.

Lizieri (2009), as cited in Emele, Okpaleke and Umeh (2014), divides forecasting methodologies into two groups: formal and intuitive. Formal forecasting, which is the more commonly adopted approach, is further defined by two main approaches, namely: quantitative and qualitative approaches. The quantitative approach is analytical and has been recommended by many studies given its emphasis on historic data for estimated outcomes. Various international studies (United Kingdom (UK)- Gardiner and Henneberry, 1989; McGough and Tsolacos, 1995; Brooks and Tsolacos, 2001; Stevenson, 2007; Papastamos, Matysiak and Stevenson, 2014; Hong Kong - Tse, 1997; Finland - Karakozova, 2005; Kiehela and Falkenbach, 2014; Australia Newell and MacFarlane, 2006; Singapore - Ng and Higgins, 2007) concentrate on the application of quantitative forecasting methods in real estate. These methods include the Box Jenkins, Auto Regressive Integrated Moving Average (ARIMA), ARIMA with a vector of an explanatory variable (ARIMAX), Vector Auto Regression (VAR), Ordinary Least Square Regression (OLS)/Simple Regression and Multiple Regression amongst others, in the real estate investment market. Jadevicius and Huston (2015) citing and expanding on Lizieri's (2009) work, further classify quantitative forecasting methods into two classes; simple and complex. They include Exponential Smoothing, Simple Regression, Multiple Regression and ARIMA models into the simple forecasting technique category. Econometric and VAR specifications are classified as complex forecasting techniques.

Despite the international emphasis on forecasting for real estate outcomes, empirical studies on real estate investment and forecasting in Lagos remain limited. The Nigerian literature (Oni, 2009; Oni, Bello \& Oni, 2012; Oyewole, 2013; Iroham et al., 2013; Emele, Okpaleke \& Umeh, 2014; Udoekanem, Ighalo \& Sanusi, 2015) consider various perspectives on the performance and forecasting of real estate investment. However, few focus on the prediction of total returns. In response, this study attempts to forecast the future performance, in terms of total returns, of shop and office investments in five selected commercial centres in Lagos Metropolis. Total returns are the unit of analysis because it is one of the recognised main measures of investment performance; it shows the investor both capital appreciation and income return on the investment (Crosby \& Devaney, 2019). 
Therefore, the enquiry into this measure of performance gives a more comprehensive assessment of the performance of commercial property investments. The total returns were determined by applying the annual rent and capital values of the commercial property investments as inputs, before predicting the future total returns.

The choice of Lagos Metropolis is predicated on its position as the largest property market in Nigeria where property investment take place (Olapade \& Olaleye, 2018; 2019). The study areas considered are; Yaba, Ikeja, Lagos Island, Ikoyi and Victoria Island. They were selected in line with Umeh, Otegbulu and Anule's (2016) rationale, who similarly observed that these areas reasonably cover the core commercial areas in Lagos Metropolis and the results can be generalised to every commercial area in Lagos Metropolis. The next section presents a literature review of forecasting, investment performance studies in Nigeria as well as the issues within Nigerian real estate investment analysis. The third section presents the research methodology used and highlights the issues encountered in data collection. The fourth section presents the results and findings. The final section concludes the study and offers recommendations based on the results, findings and challenges.

\section{Literature Review}

\subsection{Forecasting techniques in commercial property performance analysis}

Studies on the forecasting of commercial property investments are predominantly foreign based, focusing on study areas in the UK, Australia, among others. These studies have focused on the application of different quantitative techniques for forecasting real estate investments. The techniques have either been time-series models (incorporating time), econometric models (incorporating time, macroeconomic variables and other variables), or models that test the accuracy of forecasts. For example, in a study based in Finland (using the Helsinki property market), Karakozova (2005) examined alternative econometric methods for modelling and forecasting property rent and returns. The study recommends that if the investment analysis aims to forecast rent and returns, a simple time-series technique should be used. The findings of Karakozova (2005) was validated by Kiehela and Falkenbach (2014) which was also based on data from the Helsinki property market. While a study by $\mathrm{Ng}$ and Higgins (2007), based on the Singapore office market, constructed a regression model to determine rent in Singapore for the period 1992 to 2005. They found that their model could reasonably capture the trend of the actual gross rent for those periods. The implication from Karakozova (2005), Kiehela and Falkenbach (2014) and Ng and Higgins' (2007) is that single equation regression models can predict movements of rental values. The use of regression method to predict rental values has also been adopted by Nigerian based studies - for example by Iroham et al. (2013) and Udoekanem, Ighalo and Sanusi (2015).

The findings of Brooks and Tsolacos (2001), based in the UK slightly differs from Karakozova (2005) and $\mathrm{Ng}$ and Higgins (2007). Brooks and Tsolacos 
(2001) compared the performance of three forecasting techniques to determine the predictability of real estate investment returns in the UK. Two of the techniques adopted in the study utilise the time-series properties of real estate investment return series; while the third one uses a Vector Auto Regression (VAR) method which incorporates financial spreads. The study found that a VAR model improves on predictions of real estate investment returns made using other simpler, univariate and naïve forecasting methods for short-term forecasts. While Jadevicus and Huston (2015), also based in the UK, compared the forecast accuracy of five methods namely, ARIMA, ARIMAX, simple regression, multiple regression, and VAR, concluding that the simple and complex methods do not outperform each other in forecasting. The takeaway from the study is in its comparison of simple and complex methods of forecasting. This is unlike the general assumption that complex techniques will outperform or produce more accurate forecasts than simple techniques.

Apart from the numerous quantitative techniques applied to forecasting property investment performance, it is established that macroeconomic conditions influence forecasts. Papastamos, Matysiak and Stevenson (2014) observed that property forecast is affected by macroeconomic factors - GDP, consumer spending, inflation rate and unemployment rate. They argue that the greater the uncertainty (cross-sectional variance) of the forecasts, the greater the mean absolute errors of the property forecasts and in turn the smaller their accuracy. Their study reveals the influencing power macroeconomic factors place on forecasts which is important here given that the Nigerian macroeconomic space has been reported to experience fluctuations and volatility since 2014 . This has affected rental values and prices (Nairametrics, 2020). This may introduce greater uncertainties in forecasts of investments based in Lagos Metropolis, Nigeria.

Having identified several forecasting techniques and the impact of macroeconomic factors on forecasts, it is important to establish a forecasting technique that applies to this study.

\subsection{Preferred forecasting technique: The case for a simple regression method}

As indicated above, there are a plethora of quantitative forecasting methods applied in the domain of property investments. Therefore, the choice of an appropriate technique is a fundamental determinant in the forecasting of the total returns of investments. Academics continue to debate 'best practice' for quantitative real estate forecasting. Jadevicius and Huston (2015) investigate whether complex forecasting techniques outperform simple techniques. Their study compares the forecasting accuracy of five different techniques in forecasting the UK commercial property market rents (ARIMA, ARIMAX, simple regression, multiple regression, and VAR) as well as the forecasting accuracy of 169 specifications in a five-year out-of-sample period with 845 forecasts generated in total. The study notes that more complex VAR specifications did not produce accurate out-of-sample forecasts when compared to simple models- the simple regression and ARIMA techniques 
produced greater modelling results. The study confirms that increased model complexity does not necessarily yield greater forecasting accuracy. Furthermore, it recommends that analysts should make forecasts user friendly; that researchers should simplify forecasting techniques and use human judgement to aid forecasts; or employ a combination forecasting approach. Hence, this study promotes the need for approaching forecasting in a simple manner irrespective of the method applied, to encourage understanding.

Apart from Jadevicius and Huston (2015), the adoption of simple methods of forecasting is supported by other relevant literature. Armstrong (2001) opined that the naïve or simple forecasting method was as accurate as any other forecasting technique. Hence, the study argues in favour of simple methods of forecasting. Similarly, Newell et al. (2002) noted that despite the increased complexity in property market modelling methodologies, simple methods often perform as well as complex econometric structures. What's more, is that Newell and MacFarlane (2006) observed that many studies have found simple forecasting methods to be more accurate than complex econometric models. Karakozova (2005) and Umeh (2017) advocate the use of Ordinary Least Squares Regression Method- a simple technique- especially in situations where one is not analysing causal factors of performance.

From the foregoing, it is observed that there is no preferred one can conclude that both simple and complex techniques are appropriate depending on the scenario of application and provided that the forecast are tested for accuracy.

\subsection{Studies on performance of direct real estate investment in Lagos metropolis}

Analysing the performance of real estate investments is not new to Nigeria. Udoekanem, Ighalo and Nuhu (2014), Udoekanem, et al. (2015), Oyewole (2013), Odu (2011), Dabara (2014), Umeh and Oluwasore (2015), Umeh, Anule and Otegbulu (2016), among other studies, have assessed, analysed and compared the performance of different types and classes of real estate investment using different objectives and assessment metrics. S and Udoekanem et al. (2015), analyse the performance of commercial real estate investments in Minna and Wuse respectively for their association with

macroeconomic factors. Oyewole (2013) compares residential and commercial real estate investments in Ilorin to determine which of the investments present a better investment option in terms of performance. Odu (2011), Umeh and Adilieme (2019a), Dabara (2014) and Umeh and Oluwasore (2015) analyse the performance of real estate investments in Lagos, Akure and Ibadan in terms of their inflation hedging abilities. Additionally, Umeh, Otegbulu and Anule (2016), Umeh and Adilieme $(2019 b)$ assessed the potential benefits due to diversification of commercial real estate investments in selected locations in Lagos.

It is noteworthy that the literature on the performance measurement of investments in Lagos as well as other parts of Nigeria, presents an academic bias towards diversification benefits, relationship with macroeconomic 
indicators, comparing investments that present the best opportunities and inflation-hedging capabilities. There has been little focus on predicting the performance of investments based on their total returns.

Oni (2009), for one, using a polynomial regression model, focuses on the forecasting of rental values of properties located along arterial roads in Ikeja; while Iroham et al. (2013) investigate forecasting of property rental values in Akure using a simple linear regression method. Oni, Bello and Oni (2012), using the moving average method, concentrate on forecasting the demand for office spaces in Ikeja; while Udoekanem, Ighalo and Sanusi (2015) adopt a regression method in predicting the rent of offices in Abuja. Emele, Okpaleke and Umeh (2014) study the overarching limitations to the practice of real estate forecasting in Nigeria. However, these studies have not considered the total return on investment concept. Total returns capture capital appreciation and income return on the investment, it shows an investor the capital appreciation and income return measure of investment performance and is one of the recognized primary measures of investment performance (Crosby \& Devaney, 2019).

From the foregoing, it is necessary to briefly identify issues plaguing property investment analysis in Lagos Metropolis. This may reveal reasons for the absence of enquiry into the prediction of total returns of property investments in the study area.

\subsection{Some issues plaguing investment analysis in Lagos metropolis}

Real estate investment analysis in Lagos Metropolis, and by extension Nigeria, is plagued by several issues that have, in turn, limited forecasting of investment performance. Firstly, the real estate market in Nigeria is opaque and data on property transactions is rarely found in the public domain. The 2020 Global Real Estate Transparency Index report by Jones Lang LaSalle (JLL) categorised the Nigerian real estate market as having low transparency (68 out of 99 markets under review). Other prevalent issues include; averseness to data sharing and assemblage by real estate practitioners, data retention capacity of estate firms and period of data retention (Olapade \& Olaleye, 2018; Olapade \& Olaleye, 2019). The combination of these factors has also limited investment funding opportunities from European and American investors, who have rated the market a high-risk market (Lim, McGreal \& Webb, 2006).

Of the issues identified, the unavailability of publicly accessible quality data is particularly significant. This is emphasized by the absence of a central property database and a property index which in turn affects real investment analysis. Property investment analysis and forecasting, in particular, will be better served by independent and publicly verifiable data sources. Furthermore, it is observed that in developed nations (United States of America, UK, Australia, etc.), property investment performance indices are constructed monthly or quarterly to produce a robust data set (Higgins, 2015; MSCI, 2020). This allows for the capture of the real estate market cycle or an outlier occurrence within a year; annual averages may not properly capture 
the real estate market cycle. However, the practice in Lagos metropolis is that rental values used in investment performance measurements are recorded annually, preventing the development of a robust data set for analysing and forecasting investment performance in Lagos Metropolis. Besides, the issue of the absence of a data bank has also prompted the sourcing of rental values and capital values directly from real estate practitioners.

In addition, little consideration has been given to the measure of the total return on investment performance. Nevertheless, this research focuses solely on forecasting the total returns of commercial property investments. The next section is dedicated to the research methods applied in this paper.

\section{Research Methods}

The study aimed to forecast the performance (total returns) of commercial property investments in Lagos Metropolis, due to the few numbers of studies focused on that area. The study was presented with the already acknowledged issue of the absence of a central property database. Hence, the primary data originates from the archives of estate firms registered with the Estate Surveyors Registration Board of Nigeria (ESVARBON) in Lagos metropolis. 192 estate firms are considered out of the 382 firms in the area by using an online sample size calculator (www.surveysystem.com/sscalc.htm). The sample size has a 95\% confidence level and a 5\% confidence interval. From this sample, two types of properties (shops and offices) and thus their relevant data are studied in 200 properties in total. Shops and offices were considered due to their popularity in the commercial property market of Lagos Metropolis. Out of the 200 properties, 125 were offices and 75 were shops. The choice of only 200 commercial properties was because they were the number of properties whose data were reliable for the 12 years considered. The rationale behind this choice is validated by a recent relevant study in the area by Ekemode and Olaleye (2016) which covered only 226 properties due to data retention challenges faced by real estate firms in Lagos metropolis which limited the scope of data collected.

The data on the average annual capital and rental values on these properties serves as the input for determining the total returns of various commercial real estate investments. The total returns formula for the real estate investment asset is given as:

$$
T R_{t}=\left(\frac{\left(C V_{t}-C V_{(t-1)}-C \operatorname{Expt}_{t}+C R p t_{(t)}+N I_{(t)}\right.}{C V_{(t-1)}+C E x p t_{t}}\right) \times 100
$$

Where: $T R_{t}=$ the total return in for the period under review ( $\left.t\right)$

$C V_{t}=$ the capital value at the end of the period under review ( $\left.t\right)$

$C$ Expt $_{t}=$ the capital expenditure (includes developments) in period ( $t$ )

$C R p t_{t}=$ the capital receipts (includes sales) in period ( $\left.t\right)$

$N I_{t}=$ the rent receivable during period ( $\left.t\right)$, net of property

management costs, ground rent and other irrecoverable expenditures

The use of average annual capital and rental values sourced directly from real estate practitioners is due to the absence of a national property database and 
information on commercial real estate transactions. Furthermore, rental transactions occur annually in Nigeria. The absence of a property index limits the dataset to annual values as opposed to monthly and quarterly values. These observations present a limitation, as the in-sample data obtained was for 12 years (2007 to 2018); 12 observations, as opposed to 144 or 48 observations if there was a monthly or quarterly property index.

Time is an important factor in forecasting property performance. As such, a Simple Regression methodology for time-series is adopted to make a forecast on total returns. This method allows for a simple time-series which achieves the same results as complex methods of forecasting (Armstrong, 2001; Karakozova, 2005; Umeh 2017). Furthermore, the absence of a robust dataset precluded the use of complex time-series models such as the ARIMA method. The forecast is followed by a test of predictive validity for the dataset using the Autocorrelation method. Autocorrelation is applied in technical analysis to measure how much impact a past pattern will influence or have on future patterns in a time-series analysis. Umeh (2017) observes that autocorrelation is used in an econometric analysis to determine if a past pattern is likely to continue in the future, provided that all external conditions remain constant. An investment possessing a high probability of pattern continuity suggests that trends can be forecasted with a relatively high level of confidence. The autocorrelation method is given as:

$$
r_{k}=\frac{\sum_{t=k+1}^{n}\left(x_{t}-\bar{x}\right)\left(x_{t-k}-\bar{x}\right)}{\sum_{t=1}^{n}\left(x_{t}-\bar{x}\right)^{2}}
$$

Where: $r_{k}=$ the autocorrelation coefficient with $k$ period lag

$\bar{x}=$ the mean of $x$ variables

$x_{t}=$ the observation of the period $t$

$x_{t-k}=$ the observation of $x$ with $k$ period lag

$n=$ the number of observations of $x$

The results are given on a scale of -1 to +1 , with +1 indicating a perfect positive correlation and -1 indicating a perfect negative correlation. Higher autocorrelation values indicate high predictive validity (the past pattern will continue) (Umeh, 2017). The time-lag used for the autocorrelation analysis in this study is a 3-year time-lag.

In forecasting, it is essential to evaluate the accuracy of forecasts (Newell \& MacFarlane, 2006; Jadevicius \& Huston, 2015). Forecast evaluation compares the forecast values and actual values and inference from the result can be made concerning the accuracy of the forecast. Hence, the forecasts were evaluated using the Root Mean Squared Error, Mean Absolute Error, Mean Absolute Percentage Error, and Theil Inequality Coefficient methods on EViews software. The methodology adopted by the study commences with sourcing rental and capital values, determination of the total returns. These total returns are used to predict the total returns for 2019 to 2021. The total returns are tested for their predictive validity, then, the predicted values are evaluated for accuracy, by applying forecast evaluation techniques.

\section{Results and Findings}


This section presents the results and findings from the analysis conducted on relevant data obtained for this paper. Table 1 presents the average annual total returns for shops and offices in the selected study areas for 2007 to 2018 while the predicted total returns for 2019 to 2021 is presented in Table 2. Table 3 presents the results of the autocorrelation test, and the forecast evaluation is shown in table 4.

Table 1: Average Annual Total returns for Shops and Offices in Selected Areas of Lagos Metropolis

\begin{tabular}{|l|c|c|c|c|c|c|c|c|c|c|}
\hline & \multicolumn{3}{|c|}{ Shops } & \multicolumn{3}{c|}{ Offices } \\
\hline Year & Yaba & Ikeja & L/Island & Ikoyi & V/Island & Yaba & Ikeja & L/Island & Ikoyi & V/Island \\
\hline 2007 & $11.97 \%$ & $4.52 \%$ & $0.13 \%$ & $14.71 \%$ & $17.25 \%$ & $17.87 \%$ & $2.96 \%$ & $7.15 \%$ & $3.59 \%$ & $17.25 \%$ \\
\hline 2008 & $8.09 \%$ & $11.43 \%$ & $13.60 \%$ & $4.48 \%$ & $1.95 \%$ & $3.41 \%$ & $7.23 \%$ & $8.82 \%$ & $9.52 \%$ & $1.95 \%$ \\
\hline 2009 & $9.96 \%$ & $3.90 \%$ & $0.13 \%$ & $3.53 \%$ & $14.11 \%$ & $10.62 \%$ & $7.33 \%$ & $1.56 \%$ & $9.85 \%$ & $14.11 \%$ \\
\hline 2010 & $2.43 \%$ & $11.12 \%$ & $18.31 \%$ & $11.17 \%$ & $17.32 \%$ & $14.02 \%$ & $4.72 \%$ & $10.78 \%$ & $3.10 \%$ & $17.32 \%$ \\
\hline 2011 & $15.43 \%$ & $6.71 \%$ & $0.13 \%$ & $12.39 \%$ & $13.12 \%$ & $5.85 \%$ & $15.95 \%$ & $1.38 \%$ & $13.32 \%$ & $13.12 \%$ \\
\hline 2012 & $3.99 \%$ & $7.85 \%$ & $13.98 \%$ & $12.52 \%$ & $14.90 \%$ & $10.41 \%$ & $5.56 \%$ & $10.95 \%$ & $8.28 \%$ & $14.90 \%$ \\
\hline 2013 & $3.86 \%$ & $2.49 \%$ & $0.14 \%$ & $5.88 \%$ & $10.23 \%$ & $7.78 \%$ & $0.02 \%$ & $0.03 \%$ & $2.45 \%$ & $10.23 \%$ \\
\hline 2014 & $5.14 \%$ & $25.76 \%$ & $5.29 \%$ & $2.68 \%$ & $22.31 \%$ & $1.07 \%$ & $14.40 \%$ & $1.34 \%$ & $0.77 \%$ & $22.31 \%$ \\
\hline 2015 & $4.91 \%$ & $1.95 \%$ & $2.73 \%$ & $2.86 \%$ & $0.45 \%$ & $1.07 \%$ & $0.27 \%$ & $1.05 \%$ & $2.34 \%$ & $5.18 \%$ \\
\hline 2016 & $6.62 \%$ & $1.18 \%$ & $7.23 \%$ & $7.77 \%$ & $-0.29 \%$ & $11.28 \%$ & $-0.99 \%$ & $2.04 \%$ & $2.10 \%$ & $-0.27 \%$ \\
\hline 2017 & $5.02 \%$ & $1.82 \%$ & $4.65 \%$ & $5.22 \%$ & $2.44 \%$ & $5.31 \%$ & $-1.30 \%$ & $-4.19 \%$ & $-2.31 \%$ & $-0.38 \%$ \\
\hline 2018 & $0.79 \%$ & $0.11 \%$ & $0.03 \%$ & $-0.077 \%$ & $-0.41 \%$ & $1.77 \%$ & $0.40 \%$ & $-3.18 \%$ & $-1.49 \%$ & $-0.52 \%$ \\
\hline Mean & $6.52 \%$ & $6.57 \%$ & $5.53 \%$ & $6.93 \%$ & $9.45 \%$ & $7.54 \%$ & $4.71 \%$ & $3.14 \%$ & $4.29 \%$ & $9.60 \%$ \\
\hline $\begin{array}{l}\text { Std. } \\
\text { Dev }\end{array}$ & $4.19 \%$ & $7.12 \%$ & $6.45 \%$ & $4.72 \%$ & $8.16 \%$ & $5.41 \%$ & $5.77 \%$ & $5.09 \%$ & $4.85 \%$ & $8.08 \%$ \\
\hline
\end{tabular}

Source: Field Survey (2019)

Table 1 presents the total returns determined for the property investment options in the five study-areas over 12 years. Real estate investments in these locations fluctuate significantly. This observation, therefore, indicates high market volatility and aligns with the findings of Lu and Mei (1999) who argue that property investment returns in emerging markets are unpredictable. Such high levels of volatility are expected to reduce predictive validity and limit forecasting (Emele, Okpaleke \& Umeh, 2014).

\section{Forecasts}

The time-series regression for the total returns from each of the locations is determined using the Ordinary Least Squares Regression method. The characteristic regression lines are given as:

Shops in Yaba:

Shops in Ikeja:

Shops in Lagos Island:

Shops in Ikoyi:

Shops in Victoria Island:

Offices in Yaba:

Offices in Ikeja:

Offices in Lagos Island:

$$
\begin{aligned}
& \mathrm{y}=10.22-0.673(\mathrm{x}) ; r^{2}=0.3357 \\
& \mathrm{y}=\mathbf{9 . 4 2}-\mathbf{0 . 5 1 8}(\mathrm{x}) ; r^{2}=0.069 \\
& \mathrm{y}=7.61-0.378(\mathrm{x}) ; r^{2}=0.0447 \\
& \mathrm{y}=\mathbf{1 0 . 8 4}-\mathbf{0 . 7 1 2}(\mathbf{x}) ; r^{2}=0.2952 \\
& \mathrm{y}=16.22-1.231(x) ; r^{2}=0.296 \\
& \mathrm{y}=\mathbf{1 2 . 1 0}-\mathbf{0 . 8 2 9}(\mathbf{x}) ; r^{2}=0.3048 \\
& \mathrm{y}=8.47-\mathbf{0 . 6 8 4}(\mathrm{x}) ; \quad r^{2}=0.1827 \\
& \mathrm{y}=\mathbf{8 . 6 6}-\mathbf{1 . 0 0 3}(\mathrm{x}) ; r^{2}=0.5046
\end{aligned}
$$


Offices in Ikoyi:

Offices in Victoria Island:

$$
\begin{aligned}
& y=9.37-0.923(x) ; r^{2}=0.4701 \\
& y=16.42-1.241(x) ; r^{2}=0.3065
\end{aligned}
$$

The fitted regression line for the investment property options shows a low coefficient of determination $(<0.70)$. This coefficient is an indication that the dataset did not fit and is due to the fluctuations observed in the in-sample total returns. This result suggests that the predictions (Table 2), made using this data, may not be reliable, as the total returns show that they are subject to other factors other than the variable of time. Other factors might be GDP and vacancy rates. Udoekanem, Ighalo \& Nuhu (2014) found that in certain commercial property markets of Nigeria, changes in return inputs such as rent is influenced by the GDP and vacancy rate of Nigeria.

\begin{tabular}{|c|c|c|c|c|c|c|c|c|c|c|}
\hline & \multicolumn{5}{|c|}{ Shops } & \multicolumn{5}{|c|}{ Offices } \\
\hline & $\begin{array}{c}\text { Yaba } \\
\text { Shops } \\
\end{array}$ & $\begin{array}{l}\text { Ikeja } \\
\text { Shops }\end{array}$ & $\begin{array}{c}\text { L/Island } \\
\text { Shops } \\
\end{array}$ & $\begin{array}{l}\text { Ikoyi } \\
\text { Shops } \\
\end{array}$ & $\begin{array}{c}\text { V.I. } \\
\text { Shops }\end{array}$ & $\begin{array}{c}\text { Yaba } \\
\text { Office }\end{array}$ & $\begin{array}{l}\text { Ikeja } \\
\text { Office }\end{array}$ & $\begin{array}{c}\text { L/Island } \\
\text { Office }\end{array}$ & $\begin{array}{l}\text { Ikoyi } \\
\text { Office }\end{array}$ & $\begin{array}{l}\text { V.I. } \\
\text { Office }\end{array}$ \\
\hline 2019 & $1.46 \%$ & $2.68 \%$ & $2.69 \%$ & $1.59 \%$ & $0.22 \%$ & $1.32 \%$ & $-0.42 \%$ & $-4.38 \%$ & $-2.63 \%$ & $0.29 \%$ \\
\hline 2020 & $0.79 \%$ & $2.17 \%$ & $2.31 \%$ & $0.88 \%$ & $-1.02 \%$ & $0.49 \%$ & $-1.10 \%$ & $-5.39 \%$ & $-3.55 \%$ & $-0.95 \%$ \\
\hline 2021 & $0.12 \%$ & $1.65 \%$ & $1.93 \%$ & $0.16 \%$ & $-2.25 \%$ & $-0.34 \%$ & $-1.79 \%$ & $-6.39 \%$ & $-4.47 \%$ & $-2.19 \%$ \\
\hline
\end{tabular}

Table 2: Predicted Total Returns for 2019-2021

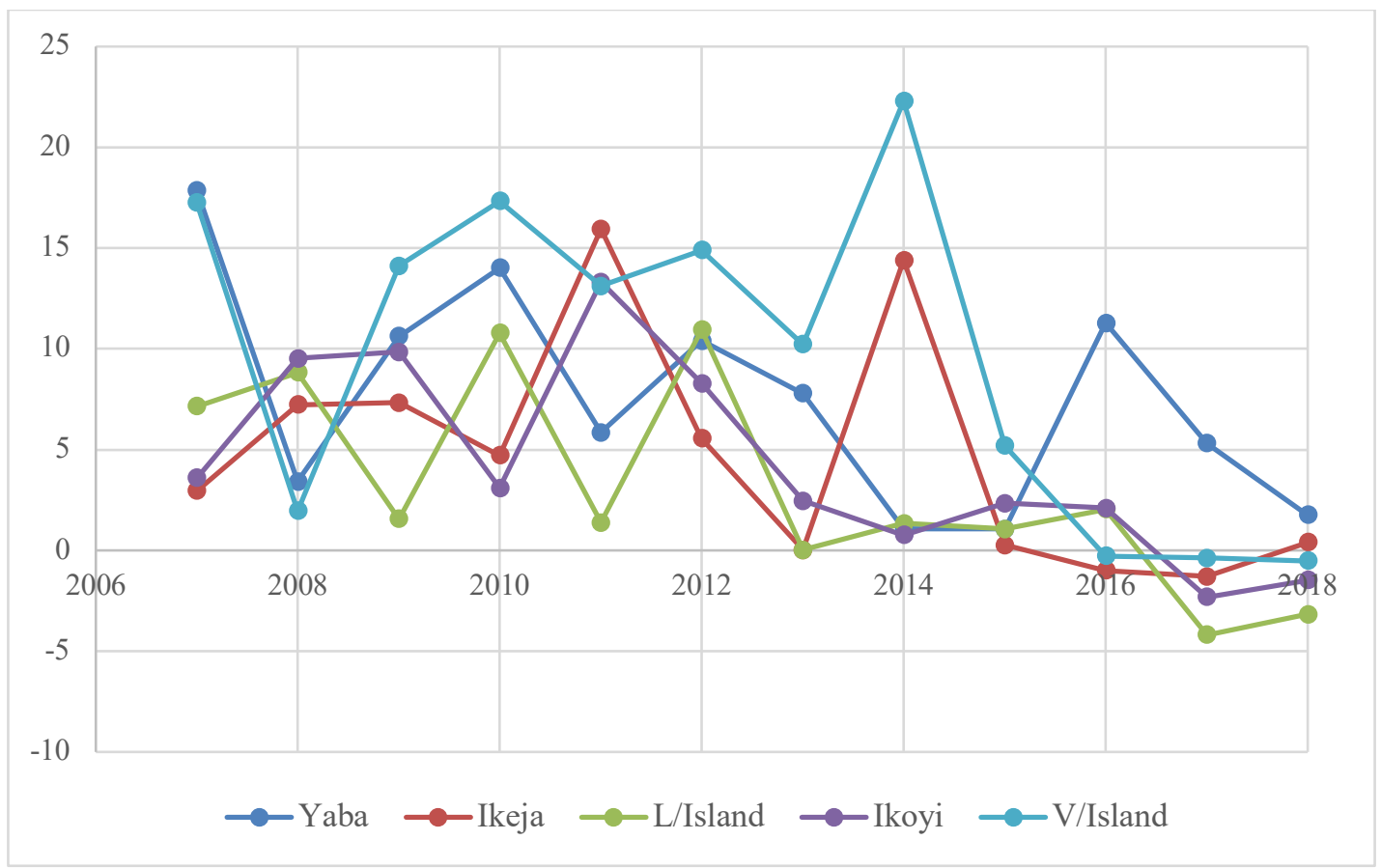

Figure 1: Trendline Of Total Returns On Shop Investments

The total returns on shop investments, illustrated in Figure 1, fluctuated between 2007 and 2016 with sharp rises and falls in the total returns particularly between 2009 and 2014. The total returns experienced a downward trend from 2016 to 2018. These fluctuations may be the result of the low growth observed in the rental values as well as the decline in capital values. Oxford Business Group (2019), in a study on the performance of the Nigerian real estate sector, reports that the real estate sector was impacted negatively by an economic downturn which was marked by a drop in the price 
of crude oil. According to them, this decline was noticeable from 2013 to 2018 , with the situation worsened by political instability brought about by a change in regime in 2015.

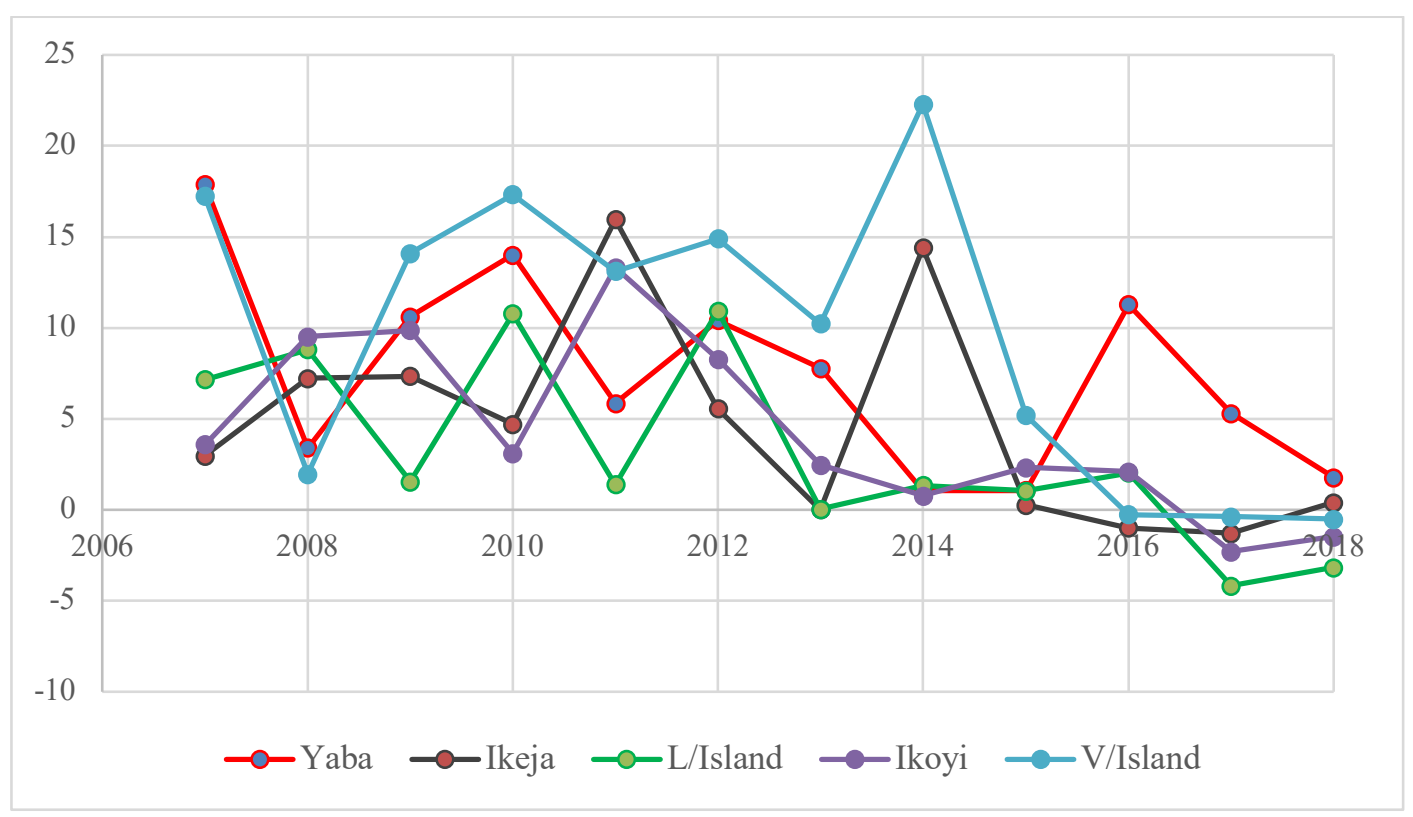

Figure 2: Trendline of Total Returns on Office Investments

As seen in Figure 2, the trend of total returns on office investments, like the shop investments in the study areas, fluctuated between 2007 and 2018 with sharp rises and falls in the total returns particularly between 2009 and 2014. These fluctuations may be the result of similar factors identified for the shop investments as reported by Oxford Business Group (2019). With these trends in mind, one can investigate the predictive validity of commercial investment opportunities across the five study areas (Table 3 ).

Table 3: Predictive Validity for the Commercial Investment Options

\begin{tabular}{|c|c|c|c|}
\hline Investment option & 1-time lag & 2-time lag & 3-time lag \\
\hline Yaba Shops & -0.197 & +0.202 & -0.017 \\
\hline Ikeja Shops & -0.225 & +0.053 & +0.131 \\
\hline L/Island Shops & -0.689 & +0.664 & -0.530 \\
\hline Ikoyi Shops & +0.210 & -0.242 & -0.061 \\
\hline V.I. Shops & +0.158 & +0.187 & +0.075 \\
\hline Yaba Office & -0.093 & -0.104 & +0.401 \\
\hline Ikeja Office & +0.013 & -0.008 & +0.337 \\
\hline L/Island Office & +0.057 & +0.426 & +0.004 \\
\hline Ikoyi Office & +0.413 & +0.160 & +0.276 \\
\hline V.I. Office & +0.259 & +0.164 & -0.008 \\
\hline
\end{tabular}

Table 3 presents the result of the autocorrelation analysis. The predictive validity of the total returns in the submarkets of Lagos metropolis varied from submarket to submarket as well as from time lag to time lag. In the case of the one-time lag; the predictive validity is higher for Ikoyi shops, Victoria Island shops, Ikoyi offices, and Victoria Island offices. In the case of the two- 
time lag, the predictive validity is higher for Lagos Island shops, Lagos Island offices, and Yaba shops and very low for Ikoyi shops. In the case of the three time-lag, predictive validity is substantially higher for Yaba offices, Ikeja offices, and Ikoyi offices. As such, the investment options that show promise of pattern-continuation into the near future, based on its autocorrelation, are shops in Victoria Island, offices in Lagos Island, and offices in Ikoyi. This implies that the predictions made for these investments for 2019 to 2021, using the Ordinary Least Square regression method have a strong likelihood of occurring.

In general, the autocorrelation results suggest that the total returns observed in-sample will not follow the same pattern in the future. This holds as the Nigerian property market experienced volatility, marked by fluctuations in real estate values (capital and rental prices) in the period under review (2014 to 2019) (Oxford Business Group, 2019; Nairametrics, 2020).

\section{Evaluation of the accuracy of the forecast}

Forecast accuracy refers to the closeness of the predicted values to the true values obtained for the study. The accuracy of the forecasts was evaluated for accuracy using four techniques Root Mean Squared Error, Mean Absolute Error, Mean Absolute Percentage Error, and Theil Inequality Coefficient, with the aid of the EViews software (a statistical software used for forecasting, modelling, etc). The results are presented in Table 4 below.

Table 4: Forecast Evaluation

\begin{tabular}{|l|c|c|c|c|c|c|}
\hline Forecast & RMSE & MAE & MAPE & SMAPE & Theil U1 & Theil U2 \\
\hline YABA Shops & 1.382474 & 1.376667 & 67.28138 & 108.3539 & 0.436385 & 2.853196 \\
\hline IKEJA Shops & 0 & 0 & 0 & 0 & 0 & 0 \\
\hline L/ISLAND Shops & 0.180831 & 0.143333 & 7.931481 & 7.421633 & 0.03985 & 0.454919 \\
\hline IKOY Shops & 1.300295 & 1.29 & 63.47389 & 100.095 & 0.398819 & 2.740338 \\
\hline V/ISLAND Shops & 3.237164 & 3.183333 & 158.3864 & 189.8851 & 0.889568 & 7.04461 \\
\hline YABA Offices & 1.69628 & 1.676667 & 82.92389 & 131.4386 & 0.557368 & 3.630149 \\
\hline IKEJA Offices & 3.272945 & 3.27 & 158.2826 & 200 & 0.950307 & 6.537388 \\
\hline L/ISLAND Offices & 7.563923 & 7.553333 & 366.3642 & 200 & 0.987986 & 15.21796 \\
\hline IKOYI Offices & 5.726223 & 5.716667 & 277.546 & 200 & 0.98124 & 11.55829 \\
\hline V/ISLAND Offices & 3.172386 & 3.116667 & 155.2284 & 186.9809 & 0.88233 & 6.922176 \\
\hline Simple mean & 2.715407 & 2.704 & 132.1555 & 187.3059 & 0.885865 & 5.60382 \\
\hline Simple median & 2.355621 & 2.33 & 115.0357 & 169.2013 & 0.788039 & 5.028141 \\
\hline Least Squares & $1.41 \mathrm{E}-15$ & $1.41 \mathrm{E}-15$ & $6.66 \mathrm{E}-14$ & $6.84 \mathrm{E}-14$ & $3.19 \mathrm{E}-16$ & $2.85 \mathrm{E}-15$ \\
\hline Mean square error & $\mathrm{NA}$ & $\mathrm{NA}$ & $\mathrm{NA}$ & $\mathrm{NA}$ & $\mathrm{NA}$ & NA \\
\hline MSE ranks & 2.566944 & 2.555152 & 124.9836 & 181.6657 & 0.86187 & 5.311498 \\
\hline
\end{tabular}

* Trimmed mean could not be calculated due to insufficient data

Finally, this study evaluated the accuracy of the forecasts using four measures: Root Mean Squared Error, Mean Absolute Error, Mean Absolute Percentage Error, and Theil Inequality Coefficient with EViews v.10 software. The accuracy test returned poor results for all investment options excluding shops in Lagos Island, indicating that the predicted total returns do 
not follow the observed total returns. Hence, the forecasts made using the ordinary least square regression method may not be relied upon.

\section{Conclusion and Recommendations}

The importance of forecasting possible investment outcomes cannot be overemphasized. It gives investors a probable snapshot into future outcomes of different investments thus guiding the investors to better alternatives. Hence, this study attempted to forecast the performance, in terms of total returns, of commercial property investments in Lagos Metropolis for 2019 to 2021 using annual total return data for 2017 to 2018 . The forecast made use of the Ordinary Least Square Regression method for time-series data and illustrated a decline in total returns for the 2019 to 2021 period. The regression line for the investment options (shops or offices) showed a low coefficient of determination which suggests that the in-set sample data did not fit properly. The autocorrelation results also indicated low predictive validity. While the results from the forecast evaluation suggest inaccuracy in the 3year forecast made using the Ordinary Least Square Regression method for time-series data.

Summarily, these results suggest that the total returns on commercial property investments in Lagos Metropolis are influenced by other causal factors (not considered in this study) and do not increase or decrease solely, due to the passage of time. This is evidenced by the poor correlation coefficient and coefficient of determination observed from the regression line. There is a possibility that these total returns are influenced by other factors highlighted by related studies; such as macroeconomic conditions (GDP, inflation rate, vacancy, unemployment etc), market cycles, etc.

To achieve more reliable forecasts, in terms of total returns for commercial property investments in Lagos, this study recommends that studies consider the factors that influence the performance such as macroeconomic factors (GDP, inflation rate, unemployment rate, vacancy rates etc.), and market cycles. Furthermore, the absence of data remains a challenge for property professionals. As such, institutions and organisations guiding real estate in Nigeria should work toward a reliable and established database. This will enable retention and centralise property investment data and, in turn, promote fidelity of the data and allow ease of performance analysis.

\section{References}

Armstrong, J.S. (2001). Evaluating Forecasting Methods. In Principles of Forecasting: A Handbook for Researchers and Practitioners. Armstrong, J.S. (Ed.). Boston: Springer. pp.443-472.

Brooks, C. \& Tsolacos, S. (2001) Forecasting Real Estate Returns Using Fin ancial spreads. Journal of Property Research, 18(3), pp. 235-248.

Crosby, N. \& Devaney, S. (2019) Appraisal based indices. In The Routledge Companion to Real Estate Investment. MacGregor, B.D., Schulz, R. \& Green, R.K. (Eds.). Abingdon: Routledge. pp.172-191. 
Dabara, D.I. (2014). Inflation Correlation with Commercial Real Estate' Investment Returns in Akure, Nigeria. Journal of Scientific Research \& Reports. 3(23), pp 2998-3017.

DeLurgio, S. (1998). Forecasting Principles and Applications. Boston: Irwin McGraw Hill.

Ekemode, B.G. \& Olaleye, A. (2016). Convergence between Direct and Indirect Real Estate Investments. Journal of Financial Management of Property and Construction, 21(3), pp. 212-230.

Emele, C.R., Okpaleke, F.I. \& Umeh, O.L. (2014). Commercial Real Estate Market Forecasts: Complexities, Methodologies and Opportunities in the Lagos Mega City. In proceedings of the 14th AfRES Annual Conference, 2-5 ${ }^{\text {th }}$ September, Cape Town, South Africa. pp.175-200.

Gardiner, C. \& Henneberry, J. (1989). The Development of a Simple Regional Office Rent Prediction Model. Journal of Valuation. 7(1), pp.36-52.

Hargitay, S.E. \& Yu, S.M. (1993). Property Investment Decisions. A Quantitative Approach. London: E \& FN Spon.

Higgins, D. (2015). Defining the three Rs of commercial property market performance: Return, risk and ruin. Journal of Property Investment and Finance, 33(6), pp.481-493.

Iroham, C.O., Oluwunmi, A.O., Simon, R.F. \& Akerele, B.A. (2013). Assessing the Trend in Rental Values of Commercial Properties in Commercial Hub of Akure, Nigeria. International Journal of Sustainable Land Use and Urban Planning, 1(2), pp.32-45.

Jadevicus, A. \& Huston, S. (2015). Property Market Modelling and Forecasting: Simple vs Complex Models. Journal of Property Investment and Finance, 33(4), pp.337-361.

Karakozova, O. (2005). Modelling and Forecasting Property Rents and Returns. Unpublished PhD thesis. Swedish School of Economics \& Business Administration, Finland.

Kiehela, S. \& Falkenbach, H. (2014). Modelling and Forecasting Central Helsinki Office Rents. International Journal of Strategic Property Management, 18(3), pp.292-306.

Jones Lang LaSalle. (2020). Global Real Estate Transparency Index Report. [Online]. Available at: https://www.jll.com.co/en/trends-andinsights/research/2020-global-real-estate-transparency-index

(Accessed: 1 November, 2020).

Lim, L.C., McGreal, S. \& Webb, J.R. (2006). Perception of Real Estate Investment Opportunities in Central/South America and Africa. Journal of Real Estate Portfolio Management, 12(3), pp. 261-276.

Lu, K. \& Mei, J. (1999). The Return Distributions of Property Shares in Emerging Markets. Journal of Real Estate Portfolio Management, 5(2), pp.145-160.

McGough, T. \& Tsolacos, S. (1995). Forecasting Commercial Rental Values Using ARIMA Models. Journal of Property Valuation and Investment, 13(5), pp.6-22.

Mitchell, P.M. \& McNamara, P.F. (1997). Issues in the Development and Application of Property Market Forecasting: The Investor's Perspective. Journal of Property Finance, 8(4), pp.363-376. 
MSCI. (2020). MSCI Property Indexes Methodology: Index construction objectives, guiding principles and methodology for the MSCI Property Indexes. MSCI. [Online]. Available at: https://www.msci.com/documents/1296102/1311232/MSCI+Propert y+Fund+Indexes+Methodology.pdf/c6aa6d08-aba2-e608-be91d69d53864256 (Accessed: 1 November, 2020).

Nairametrics. (2020). Real Estate: Still not out of the woods. Niametrics. [Online]. Available at: https://nairametrics.com/2020/03/12/realestate-still-not-out-of-the-woods/ (Accessed: 8 August, 2020).

Newell, G., Acheampong, P. \& Karantonis, A. (2002). The Accuracy of Property Forecasting. Proceedings of the Pacific Rim Real Estate Society Conference, January $21-23$, Christchurch. pp. 1-11. Available at: http://prres.net/Papers/Newell_The_accuracy_of_property_forecasti ng.pdf. (Accessed: 5 November, 2019).

Newell, G. \& MacFarlane, J. (2006). The Accuracy of Commercial Property Forecasting in Australia. Pacific Rim Property Research Journal, 12(3), pp. 311-325.

Ng, B.F. \& Higgins, D. (2007). Modelling the Commercial Property Market: An Empirical Study of the Singapore Office Market. Pacific Rim Property Research Journal, 13(2), pp.176-193.

Odu, T. (2011). An Analysis of Relative Inflation Hedging Capacities of Prime Commercial Properties in Lagos. Global Journal of Human Social Science. 11(10), pp. 43-52.

Ogbuefi, J.U. (2002). Aspects of Feasibility and Viability Studies. Enugu: Institute for Development Studies.

Olapade, D.I. \& Olaleye, A. (2018). Resolving the data debacle in commercial property: Are property practitioners in opaque markets ready for data sharing and assemblage. Journal of Property Investment \& Finance, 36(3), pp.295-304.

Olapade, D.I. \& Olaleye, A. (2019). Factors affecting accessibility to property data in an opaque market. Property Management, 37(1), pp.82-96.

Oni, A.O. (2009). Developing Predictive Models of Commercial Property Values in Emerging Economy: Case Study of Ikeja, Nigeria. In proceedings of the 9th African Real Estate Society. 20-23 $3^{\text {rd }}$ October, Lagos, Nigeria. pp.1-23.

Oni, T. O., Bello, M.O. \& Oni, A.O. (2012). Forecasting Demand for Office Spaces in Ikeja, Nigeria. Mediterranean Journal of Social Sciences. 3(1), pp.323-338.

Oxford Business Group. (2019). Real Estate Prices in Nigeria Grow Steadily. Oxford Business Group. [Online]. Available at: https://oxfordbusinessgroup.com/overview/building-upwardsproperty-prices-have-been-impacted-oscillating-oil-receipts-arenow-growing (Accessed: 5th November, 2019).

Oyewole, M.O. (2013). A Comparative Analysis of Residential and Retail Commercial Property Investments Performance in Ilorin, Nigeria. Journal of Economics and Sustainable Development. 4(3), pp.199208.

Papastamos, D., Matysiak, G. \& Stevenson, S. (2014). A Comparative Analysis of the Accuracy and Uncertainty in Real Estate and 
Macroeconomic Forecasts. Real Estate and Planning Working Paper No. 06/14. Henley Business School, University of Reading. [Online]. Available at: http://centaur.reading.ac.uk/36850/1/wp0614.pdf (Accessed: 5 November, 2019).

Stevenson, S. (2007). A Comparison of the Forecasting Ability of ARIMA Models. Journal of Property Investment \& Finance. 25(3), pp.22-240.

Tse, R.Y.C. (1997). An application of the ARIMA model to real-estate prices in Hong Kong. Journal of Property Finance. 8(2), pp.152-163.

Udoekanem, N.B., Ighalo, J.I. \& Nuhu, M.B. (2014). Determinants of Commercial Property Rental Growth in Minna, Nigeria. EUL Journal of Social Sciences. 5(1), pp.60-75.

Udoekanem, N., Ighalo, J., \& Sanusi, Y. (2015). Predictive Modelling of Office Rent in Selected Districts of Abuja, Nigeria. Real Estate Management and Valuation. 23(4), pp.95-104.

Udoekanem, N.B., Ighalo, J.I., Sanusi, Y.A. \& Nuhu, M.B. (2015). Office Rental Determinants in Wuse Commercial District of Abuja, Nigeria. University of Mauritius Research Journal, 21, pp.1-26.

Umeh, O.L. \& Oluwasore, O.A. (2015). Inflation Hedging Abilities of Residential Properties in Selected areas of Ibadan Metropolis. ATBU Journal of Environmental Technology. 8(2), pp.93-106.

Umeh, O.L., Otegbulu, A.C. \& Anule, S.A. (2016). Minimizing Risk through Diversification of Commercial Property Investment in Selected Submarkets of Lagos. Journal of Contemporary Issues in Real Estate, $3(1)$, pp.33-41.

Umeh, O.L. (2017). Research Methodology. Lagos: UniLag Press and Bookshop Ltd.

Umeh, O.L. \& Adilieme, C.M. (2019a). Inflation-Hedging Capabilities of Commercial Real Estate Investments in Metropolitan Lagos. The Lagos Journal of Environmental Sciences. 10(1), pp.40-47.

Umeh, O.L. \& Adilieme, C.M. (2019b). Diversification Potentials of Commercial Real Estate in Metropolitan Lagos. The Lagos Journal of Environmental Sciences, 10(1), pp.61-68. 